\title{
The New Relationship Among State, Market, and Political Actors in Public Policies*
}

\author{
Pablo Eduardo Neder \\ Complutense University of Madrid, Madrid, Spain
}

\begin{abstract}
The aim of this work consists in analyzing the new relationship among the institutions, the market, and the political actors on their historical approach, sociological and from rational choice, which comes out as a set of rules that determine the institutional reform's processes from the incentive frameworks and restrictions imposed to the behaviors of the different agents and economic actors, social and political factors for the formulation and implementation of public policies and that they have an impact on the results measured in terms of economic growth and development. In this work, policies of employment form Spain (2008-2012) and Argentina (2001-2010) will be analyzed in a comparative study and in a crisis context. The author has considered that the cases are particularly adequate to answer to the new relation among the state, the market, and the political and economic actors and how they impact on the formulation and implementation of employment policies. The research conducted is of comparable hypothesis. Interviews and documentation studies were carried out that allowed observing the impact of that relationship to the policies of employment.
\end{abstract}

Keywords: state, market, public policies, political actors

The proposed work consists of, on the one hand, to note the new correlation among state, market, and society in the post-crisis of 2001 in Argentina, as a result of different law conflicts or of installation of companies that from one way or another, affect the citizens as regards quality of life, which beyond the problems and considering that "the neoliberal policies implemented in Latin America as because of the great debt crisis of the $80 \mathrm{~s}$ managed to control inflation, but failed to promote a true macroeconomic stability and recover the development" (Besser-Pereira, 2007). On the other hand, this work consists on describing and explaining the political process of the labor market's reform in Spain by the social democratic government, from the crisis of late 2007 to early 2008 to signing up with the social partners in 2011. This work explains from the conception of the public policies and the political actors, how does social dialogue develop in a context of uncertainty, because of this, it modifies the relationship among the state, the market, and the political actors. In this respect, we can quote Sartori that says the following:

Apparently, it would be a problem of redefinition of the limits and relations between the state, the market, and civil society. In our opinion, an incipient struggle can be verified from the latter to win new opportunities for debate and participation.

\footnotetext{
* The paper is partially funded by CSU from Sociological Center and Policies of Paris (CNRS), France.

Corresponding author: Pablo Eduardo Neder, Ph.D. candidate in government and public administration, Faculty of Political Sciences and Sociology, Complutense University of Madrid, Spain; and Urban Cultures and Societies (CSU) from Sociological Research Center and Policies of Paris (CNRS), France; research fields: public policy, government, European governance, comparative politics, market, and political actors. E-mail: pabloneder@hotmail.com.
} 
But is society really winning in advancing in social achievements? Or are the markets? Which is nowadays the real state's role? There are many questions that come to redefine the relationship among the state, the market, and society.

The first part of this work explains the international scenario and the impact of the financial crises; the second part describes the labor market in Argentina and the search of employment restructuration between the state and society; the third part is about the institutionalism's role in the correlation among the state, the market, and civil society, making reference to Argentina and Spain; and the last part is about the Labor Market Reform and the "Social and Economic Agreement" of the social democratic government in a context of uncertainty, with special reference to Spain.

\section{International Scenario and the Financial Crises' Impact}

The collapse of the Bretton Woods Monetary Agreements, after the oil crisis of 1973, brought the decline of national investment restrictions; at the same time, the big companies redesigned themselves to satisfy a new international clientele of investors that aspired more to gain in the short-term stock market to the benefit of long-term dividends. Analogously, jobs quickly began to cross borders. (Sennett, 2006, p. 13)

With this new international scenario, a new relation among the state, the market, and society starts to redesign itself; therefore, it has a direct implication in the formulation and implementation of the public policies, essentially in the employment policies.

Although after the Second World War, there were successive financial and economic crises in different parts of world geography,

The Great Recession of 2008-2009 has been the worst since the Second World War. The financial crisis that erupted in the United States in mid-2007 quickly became a credit crunch and the sharp drop in trade flows, with consequent loss of jobs and livelihoods for millions of people worldwide. However, the tragic consequences globally have been juxtaposing very differently between countries and regions. (Document, 2012)

This economic change is related to the regulation of redundancy costs and the types of contracts with the consequent lack of social protection in the economies of developed countries as a result of globalization, in which "Economic globalization has led to a gradual transfer of authority and power from national states to international markets" (Moreno, 2012), increasing unemployment figures to high jobless rates and in record time, with a large informal labor market economics in Mediterranean countries. Economic crisis emerged in the financial sector of the US and expanding to other countries with developed and emerging economies, causing threats to the global economic system as an evolution of a set of public policies and capitalist orientation that makes the fragility of the neoliberal system sleepless.

In this way, from the beginning of the crisis in late 2007, the labor market of the EU (European Union) (especially Spain) has been affected by the significant increase in unemployment as a result of a financial and economic crisis. In this sense, unemployment and the levels of the rates move in cycles, largely due to the general economic cycle. Nonetheless, among other factors, the relationship among the state, the market, and society in the policy changes influence on "The institutions that are important and their reform is a continuing need; because, in the complex and dynamic societies in which we live, the economic activities and the market need to be constantly regulated" (Bresser-Pereira, 2007, p. 120) and this has a direct impact on society. As Sartori points out, "One of the consequences of preferential seat that have had the market players in recent decades, without the benefit of a counterweight by civil society, has been the immense concentration of 
economic power in a few families", not only in the local market; but what is still worse, in international markets.

Before this crisis situation, governments need to develop public policies to address the circumstances that befall. In this way, they must meet the requirements that with the passage of time threaten the governance, once begun the increase in people out of work.

At present, the formulation and implementation of public policies and their reformulation are breaking high on the agenda of governments in order to maintain a high percentage of unemployed with income, disfavoring development policies. As expressed by Charles Lindblom (1991), all public policy choices have to be made at the end, not through the intellect or the analysis of any person, but by a political process. It is not the brain, but the muscle.

The EU forced itself to formulate public policies to meet those demands, through a political process where various political factors influenced political decisions when formulating such public policies.

Unemployment in Spain was constituted as the main concern for his constant and growing increase. From that moment, the political process was generated to develop employment policies and social inclusion policies to address the seriousness of this context.

In that passage, and,

In 2012, Argentina has received the brunt of the international economic context, alternating the behavior of the economy and labor market dynamics. However, as it has been shown by the latest global crack, Argentina had to reformulate a number of policies to cushion the impact of a strong international disorder in the social and working conditions of the population, and this is mainly due to the policy framework implemented since 2003 and to the new actions that complement the existing ones ${ }^{1}$. (Ministry of Labor, Employment and Social Security, 2013)

In that sense and unlike other regions in the world, an economic and financial crisis always negatively impacts in all regions of the world, and its impact on the labor market always acts to the detriment of workers, due in large part to the way a country determines its policies, as in the cases of Argentina and Spain who should rethink their policies, although both use different ways and different international contexts that definition of policies defines the new relationship between the labor market and society.

\section{Argentina's Labor Market and the Search of Labor Restructuring Between the State and Society}

Since the mid-80s, there was a profound shift in structural policies in Latin America with the implementation of neoliberal policies. In this way, the development model was replaced by a set of policies oriented to improve efficiency, facilitating the functioning of markets and reducing the distorting effects of state intervention in economic activities. (Lora, 2012)

In the 80s and during Alfonsin's government ${ }^{2}$, some privatization as articles of household and industrial machinery, ceramics and a travel agency were made between other small businesses, "However, in 1986, the government tried to deepen the privatization model as a way to address the serious fiscal imbalance" ${ }^{3}$ (Margheritis, 1998). At the same time, the IMF (International Monetary Fund) and the World Bank and with an

\footnotetext{
${ }^{1}$ Excerpt from the Ministry of Labor, Employment and Social Security. Document in reference to Argentina's employment situation in 2012 and expectations for 2013, analyzing the impact of the global crisis in the international context; economic, social, and employment situation; and finally, the productive structure as key indicators to look for relevant study.

${ }^{2}$ Raúl Alfonsín fue presidente de la Argentina desde 1983 hasta 1989.

3 Véase Margheritis A. (1998). "La política económica como instrumento político". Explica el proceso privatizador en Argentina, haciendo referencias históricas y cómo las mismas se fueron generando dentro de un marco de avance hacia las reformas estructurales.
} 
advanced economic and political crisis in Argentina exerted pressure to perform a series of structural reforms as axis of privatization policies under the mottos of efficiency and effectiveness of public enterprises in the hands of private companies, which using the same would generate more jobs.

In spite of this, beginning in the $90 \mathrm{~s}$ is given a period of contextualized debates within a strong privatization process leading to "The stagnation of Argentina's economy in the late 90s, which was combined with a strong political delegitimization of the ruling alliance and the weakening of the social frameworks that ended in an unprecedented crisis in 2001" (Delfini, Drolas, \& Montes Cató, 2014), due to release programs of their trade regimes, exchange liberalization, and greater financial liberalization with reforms that had as objective to grant greater freedom of operations to financial intermediaries, accompanied by them, tax and labor reforms, as well as policies aimed at the privatization.

As a result of that economic and financial crisis in 2001 and its continuity in 2002 in Argentina, it is established under the provisions of Article 75, Paragraph 22 of the Argentine Constitution by which constitutional status is awarded to all treaties and conventions on human rights, and in particular, the International Pact on Economic, Social and Cultural Rights of the United Nations, where family law is recognized to social inclusion.

Noting that it aims to contribute to improving the quality of life it coordinates, manages, and directs the Plan unemployed Jefas y Jefes de Hogar, nationwide, focusing attention on the areas of poverty and extreme poverty.

This program has an important component that mainly aims to combat high unemployment rate and social inclusion which also allows to modify the relationship between the state and civil society; likewise as part of restructuring of the breakdown of the social fabric, and that has the purpose of communication and distribution, beneficiary attention and institutional strengthening. It then allowed its subsequent evaluation for the creation of the Programa Familia, always linked to social inclusion and the fight against unemployment.

Following the practice of the reforms that took place during the $80 \mathrm{~s}$ and $90 \mathrm{~s}$, and in order to have a better understanding of this topic, labor policies conducted in Argentina from the government of Nestor Kirchner were implemented by "the progress and efforts of Argentina on wages, employment and social protection"4 (Document, 2013) and the budget of labor policies as the core of social inclusion as well as obtaining profits at the social condition; yet with the lack of a socio-economic development, and the need for continued investment and technological innovation and inclusion, health prevention, security, and the fight against insecurity. It stands in the programs of labor policies of the Argentine Government, the program "Jóvenes con Más $y$ Mejores Trabajos", taking development as a cornerstone of social inclusion that allows young people to get a job as part of a building model of state policies, in a global context of economic and financial crisis affecting certain developed and developing countries.

Looking at the evolution of the unemployment rate in Argentina since 2003, compared with the 90s' and in relation to the global context, it is determined that its evolution has been significant and important, and as it is mentioned in the previous paragraph, growth in recent years evolved into an economic and financial crisis with consequences in various regions of the world mainly in developed countries.

In this way, the changes in policies implemented since 2003, compared with the previous decade, had an important meaning in the social and economic structure of the country, contributing to social and labor strength that has enabled,

\footnotetext{
${ }^{4}$ See ILO report 2013-Argentina.
} 
Argentina against a contractionary global context in which it is evident in three aspects that arise from an objective reading of the indicators observed during 2012: (1) the international framework had adverse impact without substantially affecting the living conditions of the population; (2) the current economic, employment, and social situation remains one of the best in decades; and finally (3) the production structure as it is made today has an unprecedented ability to rapidly restore economic growth with job creation ${ }^{5}$.

The following table shows the employment and unemployment rates of the second, third, and fourth quarter of 2012 and the first and second quarter of 2013 over 31 urban areas in Argentina. Considering that with the advent of the crisis in 2001, Argentina once had an unemployment rate of 21.5\%; and that as of 2003, with the change in public policy and economic model, it was favored for the same with a positive impact on employment policies, because it "represents a qualitative change in the type of public policy, a change that means a review of the social right of citizenship" (Cox, 2001), such are the cases of reforms that Denmark and the Netherlands made since they are more advanced welfare states "The level of assistance aims to not only provide citizens with the means to ensure subsistence, but also give them the resources to participate fully in society" (2001). In the following figures, it can be observed that the downward trend in the unemployment rate in 2012 and the growth of $0.4 \%$ in unemployment by way of relating with unemployment in other countries as detailed below (see Table 1).

Table 1

Employment and Unemployment Rates in a Total of 31 Urban Areas

\begin{tabular}{|c|c|c|c|c|c|}
\hline \multirow{3}{*}{ Rates } & \multicolumn{5}{|c|}{31 urban areas } \\
\hline & \multicolumn{3}{|c|}{ Year 2012} & \multicolumn{2}{|c|}{ Year 2013} \\
\hline & 2nd quarter & 3rd quarter & 4th quarter & 1st quarter & 2nd quarter \\
\hline Activity & 46.2 & 46.9 & 46.3 & 45.8 & 46.4 \\
\hline Employment & 42.8 & 43.3 & 43.1 & 42.2 & 43.1 \\
\hline Unemployment & 7.2 & 7.6 & 6.9 & 7.9 & 7.2 \\
\hline Underemployment & 9.4 & 8.9 & 9.0 & 8.0 & 9.7 \\
\hline Underemployment demandant & 6.7 & 6.2 & 6.4 & 5.5 & 6.7 \\
\hline No demandant underemployment & 2.7 & 2.7 & 2.6 & 2.5 & 3.0 \\
\hline
\end{tabular}

Note. Source: INDEC, EPH Continual (2013).

In Figure 1, it is shown that unemployment from 1990 to the crisis of December 19-20, 2001, developed unevenly, and that as the government stressed more in the liberal policies, the unemployment rate increased significantly in a global context while developed or emerging economies grew at fast pace, especially the economies of the US, Europe with Germany and France leading the economic pace of the EU; and China, with an economic growth at a higher rate from other countries.

With the coming to power of President Nestor Kirchner (2003-2007), and then the current President of Argentina Cristina Fernandez de Kirchner (2007-2011 and 2011-until the second quarter of 2013), we can see that in Figure 2, how the unemployment rate drops, and how it affects the period of the global crisis on employment, while in Argentina it can be observed that unemployment increases minimally without altering the labor market.

\footnotetext{
${ }^{5}$ Information obtained from the website of the Ministry of Labor, Employment and Social Security of Argentina. Prepared by the Subsecretariat of Technical Programming and Labor Studies. Work entitled "The labor situation Argentina 2012. Expectations for 2013”.

${ }^{6}$ Demercantilization is the term used by Esping Anderson (1990) to refer to the degree of independence of the market that welfare states provide citizens, and the concept can classify welfare states as more or less demercantilized.
} 


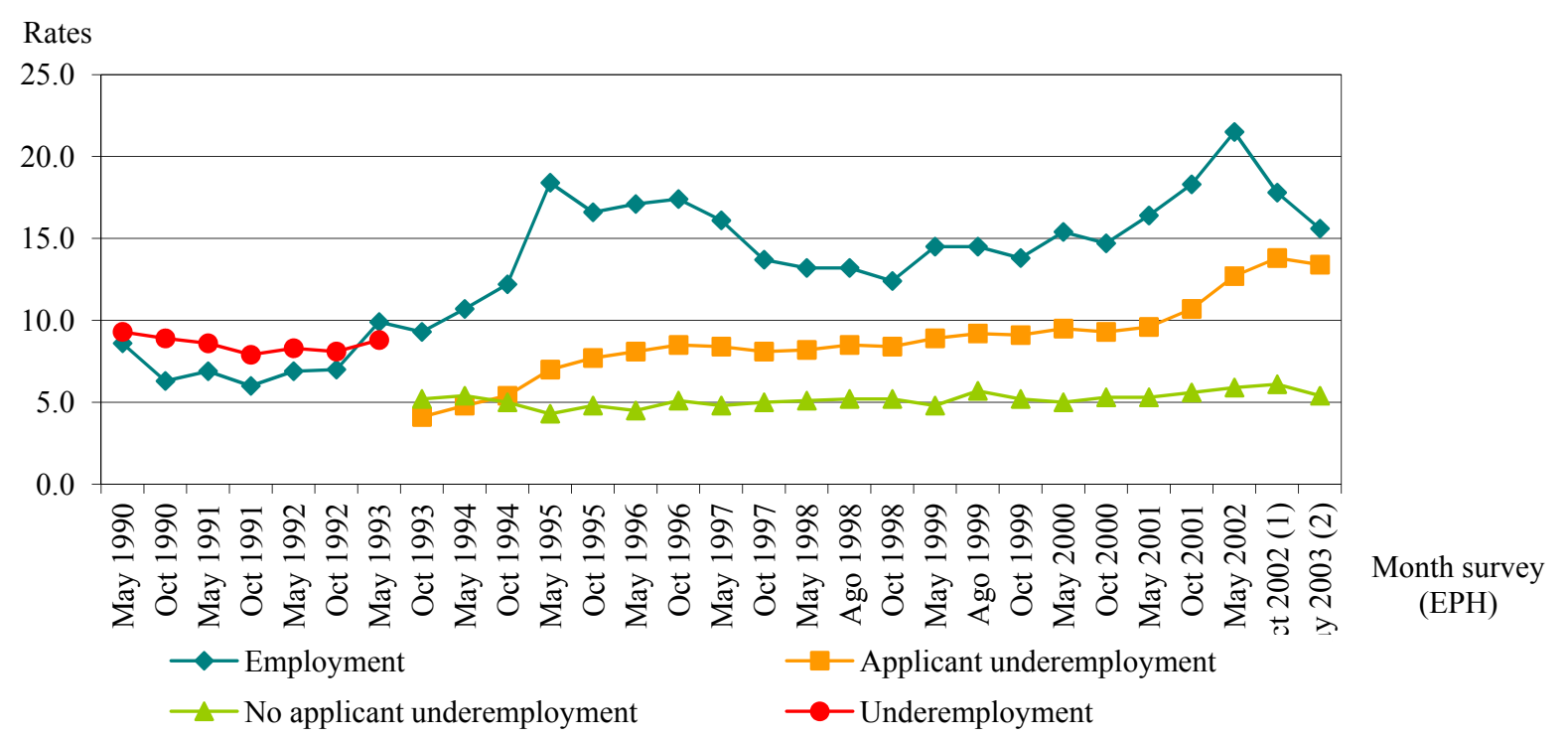

Figure 1. Unemployment rate and underemployment applicant and no applicant for total urban agglomerates from May 1990 to May 2003. Source: Prepared.

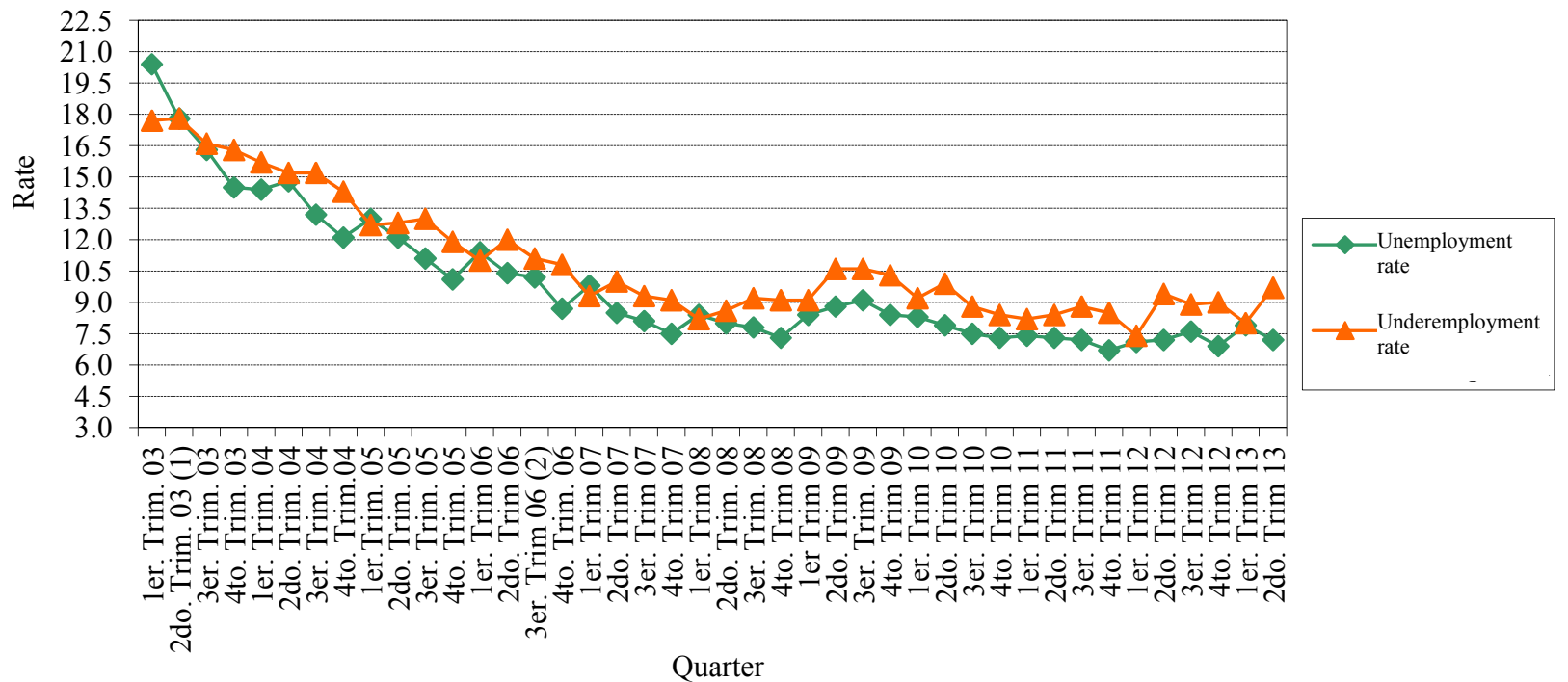

Figure 2. Quarterly evolution rates of unemployment and underemployment in the total urban agglomerates from the first quarter 2003 onwards. Source: Prepared.

While in the United States, as shown in Figure 3, the unemployment rate increases significantly from $4.80 \%$ to $7.60 \%$ at just the beginning of the crisis that is where it starts, expanding globally and affecting mainly the Mediterranean countries of Europe. Following the 2007-2008, the United States is still in deficit in the labor market without an economic equilibrium that threatened economic and political governance of the Obama administration. 


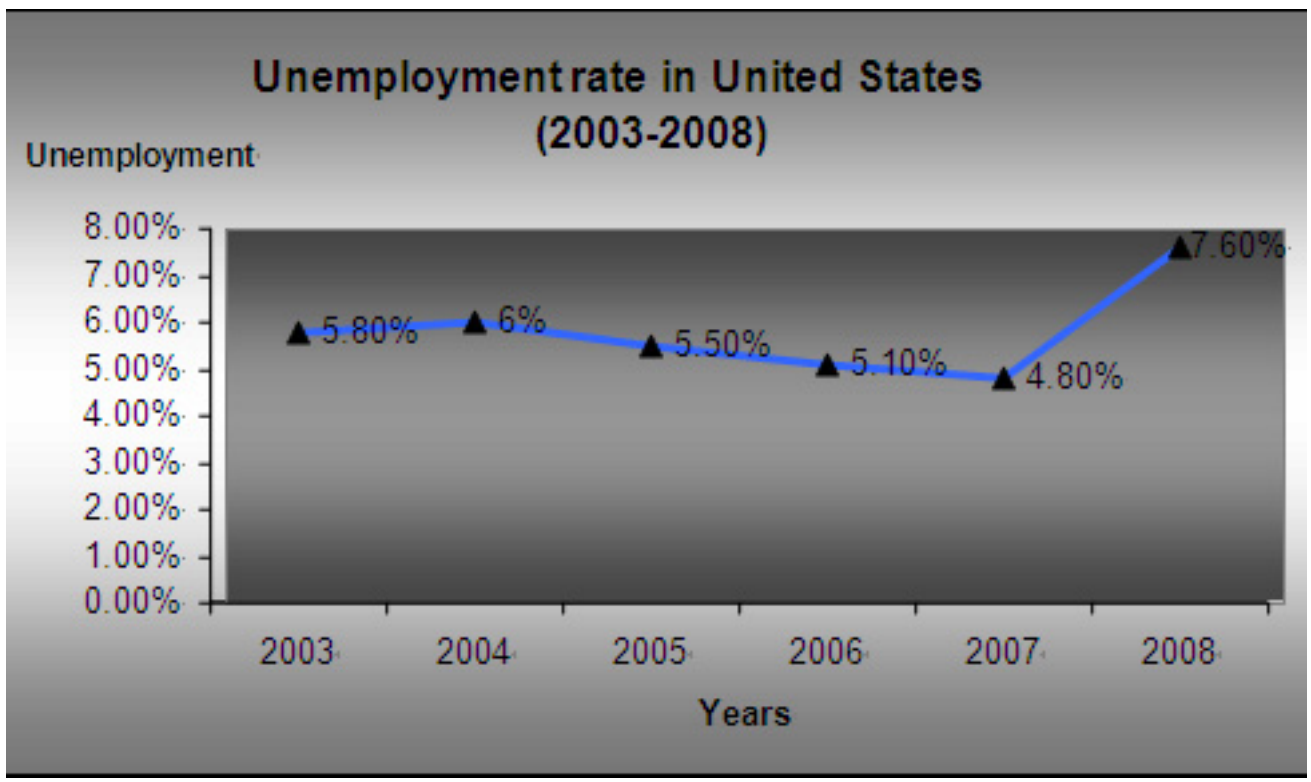

Figure 3. Unemployment rate in the United States. Source: Prepared.

\section{The Role of Institutionalism in the Correlation Among the State, Market, and Civil Society}

If we assume that the new institutionalism in its historical, sociological approaches, and rational choice that emerges as a set of rules that determine the processes of institutional reform from the frameworks of incentives and constraints imposed on the behavior of different economic, social, and politic agents and actors for the formulation and implementation of public policies that have an impact on the measured results in terms of growth and development.

From this view, the focus of the work is to point out the new balance among state, market, and society in the post-crisis Argentina in 2001, in the wake of various conflicts of laws or installation companies that beyond the problems and considering that "The neoliberal policies implemented in Latin America as a result of the great debt crisis of the 80 s managed to control inflation, but failed in promoting genuine macroeconomic stability and in regaining development" (Bresser-Pereira, 2007). However, in the government of Kirchner's presidency (from 2003), the development of social policies is, first of all, a matter for politics, determined by reference to the responsibility of the policymaker, which is immersed in a complex relationship between social action and structures from which social policies arise. From that idea, the government explains and formulates public policy and approach of historical neo-institutionalism on the role of institutions such as social, economic, and political environments, which are introduced into an unintelligible relation between social action and structures.

Impacting the 90s, March and Olsen suggested creating a new institutionalism,

That would replace the five main characteristics of political science by a conception of collective action placed in the center of the analysis. Collective action, rather than remain a riddle, as it is for economists, would became the fundamental approach to understanding political life. Furthermore, the relationship between political authorities and their socioeconomic environment should be a reciprocal relationship in which politics has the option to shape society, and society to shape politics. (Guy Peters, 2003)

In this sense, the Argentine State from 2003 has begun a process of expansion of the public sphere to the inclusion of certain industries which had been traditionally excluded. Therefore, the orientation of the policies 
was shaped for that purpose. If we refer to Adam Smith who,

Saw in the economic processes by acting as an "invisible hand", the father of economics understood the reason for personal gain produced social benefits at all understood, i.e., not persecuted by singular but resulting actors, as an indirect consequence of the mechanism they activated. Since then, the market is treated as a proven invisible hand, variously corrected, or troubled, by the intervention of the invisible hand, i.e., the state. (Sartori, 2007, p. 299)

That invisible hand, called market, has occupied an important role in Argentina of the 90s, reducing the role of the institutions and civil society to benefit big business and corporations; therefore,

It is impossible for the market to become an absolute principle, a categorical imperative, since it is merely a means to an end, not an end in itself. Arguments in favor of the market point out that if we follow their rules, large companies have developed a politics capacity and of influence that exceeds by far those of small and medium enterprises-which do have to endure the political constraints of the real market, and use this influence not only to guarantee the achievement of their objectives, but also to ensure the existence of a political system that allows the maintenance of this influence. (Crouch, 2004)

As pointed out by Laclau (2012) "Any transformation of the balance of power in the sociopolitical field cannot be verified without a profound reform of the institutions", and that is the path undertaken by the national government, performing a series of reforms for inclusive progress of the state in the public sphere; and in turn, reducing function and advance of markets. In this way, the new developmentalism mentioned by Bresser-Pereira (2007),

The new institutionalism is not a simple economic theory, but a national development strategy. It differs from the developmentalism of the $50 \mathrm{~s}$ in that it does not advocate comprehensive measures to protect an infant industry and in that although it gives the state a central role, it believes that to carry out its task, it must be financially sound and administratively efficient. Moreover, unlike conventional orthodoxy, new developmentalism is then a third discourse, a set of useful proposals for medium developed countries, such as Brazil and Argentina, to recover lost time and catch up to achieve the most prosperous nations.

He also points out that "Institutions matter and their reform is a continuing need for in the complex and dynamic societies in which we live, the economic activities and the market need to be constantly regulated. New developmentalism is then reformist". From this interpretation and from Nestor Kirchner's coming to power, it begins a new stage in Argentina with a series of reforms with a speech that dominated the crisis, with social inclusion policies and a strong presence of the state in the historical repair, and oriented to restoring the representative bond. In turn, with a political action of hegemonic intentions to carry out reforms and a policy of isolation to all its opponents and a political action toward social movements, it was as the axis of their political strategy to defend its policies.

In relation to Sartori (2007), he points out that "the more democratised the democracy, the higher the bet", and the background of this speech was the political commitment of the government to interpret all social conflicts made by social movements and citizens; because it is not just a conflict, but apparently, it was a claim for the general public to redefine the role of institutions and to set limits to the market to strengthen relations between the state and the civil society. For example, civil society as a whole approved the nationalization of Yacimientos Petolíferos Fiscal (Treasury Petroleum Fields) and Aerolineas Argentinas, because it interpreted more state control over market abuse. Consistent with the interpretation of the new institutionalists that agree with the thought that,

Institutions are the game rules of society or, more formally, the constraints or obligations created by humans that 
shape human interaction, whether political, social, or economic. Institutional change outlines how society evolves in time and is, in turn, the key to understanding historical change. (North, 1993)

However, Sckopol (1989) holds that "States conceived as organizations claiming control over territories and people may formulate and pursue goals that are not simply a reflection of the demands or interests of groups or social classes of society", which leads us to inquire into and through the following questions by Tsebelis (1990): Why institutions matter? Are the institutions a product of design or social evolution? What interests do the institutions promote: a group's or the whole society's? These are the questions that citizens do when they are hurt by certain public policies, but it is also true that when public policies are designed to benefit certain sectors of society, there are other sectors that are aggrieved. If we return to the idea of Sckopol (1989), it uses two analytical options and, while complementary, with the aim of placing the state in the forefront of historical and comparative studies of social change, politics and the development of specific policies, for this purpose, institutions must meet the primary role that is to benefit citizens through policies, as well as governance requires a well-articulated civil society. Not to mention that the institutions must be transparent and fair rules in their procedures and mechanisms to ensure the credibility of the policies promised by government actors, which as a consequence is what will build trust in civil society. In the ongoing speeches of the current President of Argentina, Cristina Fernandez de Kirchner, she supports the actions of certain groups or civil society to fight for their rights and often are channeled by institutions as a political engine is defending the interests of certain groups. But also, they performed actions for society as a whole as the aforementioned nationalizations, employment programs, laws protecting single housing, universal plan for children, retirement plan for housewives, policies that favor women, among others. That is that the present government has given an important role to the institutions and that the policies that apply to them cannot be considered sectoral or specific, because there are public policies according to the needs in relation to the priorities of government.

States can be characterized as organizations through which groups of employees can pursue general or specific objectives, meeting them with more or less effectiveness and efficiency to the state resources in relation to the social frameworks. But on the other hand, they can also be considered as configurations of action and political organization that influence the meanings and methods of politics for all groups and classes in society. He proposes this programmatic line instead of getting "entangled" in a series of cumbersome and abstract debates. Such strategies may allow the development of new historical and comparative research on the role of states on the reforms and revolutions. They can be functional for the study of design and implementation of social and economic policies developed by states, along with the influence of states in conflict and political programs. Looking at government rates ${ }^{7}$ from Néstor Kirchner's period, one can observe the $50 \%$ reduction at the levels of poverty, homelessness and unemployment, with the application of certain policies implemented by institutions that allowed social evolution. Furthermore, the implementation of other political measures such as the renewal of the Supreme Court, prosecutions for crimes against humanity, the improvement of relations with the countries of Latin America and the complete cancellation of the scourge of debt to the IMF.

As for the government of President Fernández de Kirchner, many are the policies that contributed to strengthening the institutions with a starring role of civil society in a new view of the state toward the market, reducing the latter's performance had on the $90 \mathrm{~s}$.

\footnotetext{
${ }^{7}$ See INDEC to observe the different indices.
} 


\section{Labour Market Reform and "Social and Economic Agreement" of the Social Democratic Government in a Context of Uncertainty}

Before turning to the labor market in Spain, it is significant to highlight some concepts and historical facts that will allow us to better understand the relationship among the state, the market, and society. To do this, we should mention that in the context of the EU, it is important to highlight the text of the sociologist Marshall, Citizenship and Social Class written in 1949, which raises the three dimensions of citizenship: civil, political, and social. In the latter, law circumscribes the rights of citizens in economic and social spheres, preponderating the right to work, to allow the public to exercise civil and political attributes. In these benefits posed by Marshall and Bottomore (1998), the concepts of "civil liberty and political freedom" gain strength as a counterweight to economic freedom claiming the self-regulating market.

Originated from the Industrial Revolution, it began to further affect the labor market, throwing the poor and workers to the hazards which meant that self-regulating market, inducing the public to a condition of employment vulnerability and submitting to a conflict over the break between the market and the state.

Indeed, employment policy is one of the most important challenges facing welfare states; and the environment influences together with stakeholders, resources, the effects that occur from the outside, etc., so that these developed policies are formed in a certain way and not another.

Therefore, the market plays a crucial role in its relationship with the state, and Lindblom (2000) highlights the imperfections of the market and how it affects their relationship to society, in which the market not only coordinates economic aspects; but goes further in its domain, extending to the whole of society; thus and with verbatim, he expresses categorically that "We have to think about society and not economics", further emphasizing that cooperation is the foundation of social life and is at the core of the market system (2002), influencing in the whole economy even the smallest things in people's lives. Consistent with this relationship between the market and the state, Bauman's (2001) work appears, mentioning globalization as the cause of major societal ills such as poverty, unemployment, misery, hunger, and war, among others. "The new freedom mentioned, has come to destroy all the links that have been built throughout history between the state and civil society to regulate the market" (Bauman, 2001).

Furthermore, Subirats explains that the crisis of the 70s in Spain provoked,

The general impression that this crisis is seen as the triumph of the market over the public powers; the case as a widespread phenomenon that has known in Spain, specific dimensions and concretions, resulting again in agreement with the political crisis. (Subirats, 1992)

In this context of analysis and crisis, the EU must address economic imbalances and lack of employment to provide any solution and it is affected by the dissociation between the state and the market.

The essence of the work of Viñals, Chacartegui Jávega, Ramos Martín, and Valle Muñoz (2004) of understanding state action in social life, he makes reference that uncertain environments is when social changes cause historical events, and more, opening up debates that are still valid today, we must establish the separation of the definitions of public and private spheres of economic, and scale up action of states in the socioeconomic life of the communities. Because in times of crisis, it should be taken into account some social ideas mentioned below (2004):

Helping people in all their needs, markedly those that are unemployed; the convenience of markets to have a mixed economy, which means the nationalization of strategic industries of the economy and the implementation of a welfare state 
with a social policy in order to achieve a redistribution of resources; the need to coordinate the macroeconomic policy because the market alone cannot achieve optimum results in terms of full employment.

In Europe, mainly in Mediterranean countries such as Portugal, Spain, Italy, and Greece that are the countries most affected by the financial crisis, reaching very high rates of unemployment compared with the rest of the countries of the EU, it can be observed in Spain and Greece with an unemployment rate of 26.2\%, Portugal with $16.5 \%$, and Italy with $12.2 \%$, while other countries affected by the crisis, as in the case of Ireland has a rate of unemployment of $13.6 \%$. All these countries are growing their unemployment rate by liberal practices in their policies, since they are members of a European economic governance that conditions such policies and that are more responsive to the demands of the markets to social welfare as part of a new culture of capitalism where "Modern societies granted naturalization to the market and the state as regulatory institutions of welfare and life satisfaction of citizens" (Moreno, 2000); but if we start from the concept that provides us Lindblom (2000) about "What is the market system? He says it is, like the state, a method for controlling and coordinating the behavior of the people", and from that concept we can better understand how the economy works worldwide and analyze market influences on states and thus on citizens, affecting the basic pillars of the welfare state, the labor market mainly.

In this way, the role of the state is shrinking; therefore, their social function too, and in that reduction of the state, the relationship with society is limited to certain services leading to a greater role of the markets. Thus, "State governments before efficient executors of this strategy, now become their victims. The behavior of markets-especially global finance is the main source of surprise and uncertainty" (Bauman, 2001, p. 93).

The crisis of late 2007 and early 2008 affect Spain with an increase in the rate of unemployment, and,

In countries like Spain, Greece, Ireland, and Italy that until late 2007 had spreads of BoT (Treasuries) barely higher than Germany, the problems of financing public deficits have been rising since December 2008. Despite 10 years of European single currency, the markets are operating sharp distinctions of country risk within the same single currency area, a problem that cannot be resolved simply by money creation by the member states or the emission of unionbonds, which would punish the stronger eurozone countries. All of which puts back a matter of urgency the question of a real unification of state policies, particularly social, within the European Union, especially labor policies." (Fumagalli, Lucarelli, Marazzi, Negri, \& Vercellone, 2009, pp. 27-28)

In this way, President Rodríguez Zapatero ${ }^{8}$, under pressure from the EU, influences political actors to make deep reforms, and tries by the path of social dialogue to seek a consensus to endorse the Labour Market Reform as objective of his economic policy that then captures and signs with the "Social Economic Agreement" for growth, employment and pension security with the primary objective of creating employment, promoting the livelihoods of the welfare state; and consequently, strengthen solidarity, equality, and social cohesion, with the government's commitment "to maintain an enhanced dialogue with the social partners" that participate in the signing: government, business confederations that make up the Spanish Confederation of Business Organisations (CEOE), the Spanish Confederation of Small and Medium Enterprises (CEPYME), CCOO unions (CCOO), and the General Union of Workers (UGT). The agreement consists of three main parts: the first part: (1) pensions (agreement for the reform and strengthening of the public pension system); (2) Agreement on Active Employment Policies and other matters involving labor; and (3) Agreement on Industrial Policy, Energy Policy and Innovation Policy; the second part: (4) bipartisan compromise and trade unions for the treatment of issues relating to public service; the third and final parts consist of: (5) bipartite agreement

8 José Luis Rodríguez Zapatero, two terms as president of Spain, 2004-2008 and 2008-2012. 
between the union and employer organizations on basic criteria for the reform of collective bargaining. That is the financial and economic crisis and political changes directly affect the relationship among the state, the market, and society, which in the case of Spain, this process of change is carried out directly by the state and the social partners.

An interesting contribution was reflected by Molina and Rhodes (2008), where they analyze a comparative study between Spain and Italy, saying that globalization by "Strong intervention tends to dismantle welfare states with adjustment measures, generating higher levels of lack of social protection" and describes the interaction between the actors that "converge on a high degree of institutional conflict and an apparent lack of complementarities"'.

Nevertheless, other factors are involved in the process of Labor Market Reform and that directly affects the relationship among the state, the market, and society, and therefore affects the resulting formulation of employment policies.

\section{Conclusions}

The crisis creates uncertainty, and the effects thereof on the economies of both Argentina and Spain, directly affect the relationship among state, market, and society. With this, we mentioned that the relationship among the state, the market, and society is modified as a result of the new rules and a strong state intervention in the design of public policies.

In this regard, G. O'Donnell (1993) tells us that "A state is strong if it possesses capacities on civil society", but he also adds that it needs to have "Bureaucratic, administrative capacities, if the stability of their business brains is not subject to political vicissitudes", and these political fluctuations are generated by the implementation of certain policies that favored the role of markets in detriment of civil society and with an absent state in certain functions, policies, and actions.

However, the new relationship between the state and civil society is strengthened by the decrease in the action of the market, trying to make a balance that covers the whole society. While the process of change has not yet finished, the implementation of specific policies, mainly social, allowed restoring the link between institutions and civil society. If we refer to the definition of institutions that provided by P. Hall (1993), he expresses them as "acquiescence procedures" between the different agents of the state and society that are committed in the context of the "formal institutions", but also from informal channels. Therefore, one should not forget that institutions are fundamentally political; and in that spirit, they not only act for the implementation of public policies, but also defend that these policies are correct.

With regard to the reform of the Labour Market in Spain, and how it is expressed in one of the paragraphs of "Social and Economic Agreement" to the uncertainty generated by a crisis situation, tells us the following:

All parties have shared the need that in the current state of the economy and employment, it was transcendental to recompose social dialogue and negotiation between government and social partners. The Spanish economy faces the critical challenge of generating employment and sustained growth in the long term so that the current situation can be overcome in a balanced way.

Unlike Argentina, the Spanish State being part of the EU, the rules are different, because their economic policies are framed within that context according to the objectives of European governance. Now, both

\footnotetext{
${ }^{9}$ Molina and Rhodes (2008) explain the access of reform coalitions in the political process.
} 
Argentina and Spain are in the same scenario of economic globalization; and it has consequences that affect the relationship among the state, the market, and society; and as Bauman explains, we are in a world in motion because,

The idea of the "idle", immobility, only makes sense in a world that remains stationary or attributable to this state; in a room with solid walls, rigid paths, and signs firm enough to oxidize. One cannot remain still in quicksand. Nor may he do it in our late modern or postmodern world, whose reference points are mounted on wheels and have the annoying habit of disappearing without giving us time to read the instructions, digest them, and apply them. Professor Ricardo Petrella, from the Catholic University of Louvain, summed it up nicely: Globalization drags economies in the production of the ephemeral, the volatile (by massive and widespread reduction in lifetime of goods and services) and the precarious (temporary, flexible, part-time jobs) ${ }^{10}$. (Bauman, 2001, p. 102)

By way of conclusion, it is pertinent to say that this relationship between state and society is defended by corporate policy and as mentioned by P. Evans (1996), "This comparative analysis strongly reinforces the idea that policy-makers as well as theorist can benefit from the third wave of thinking on states and development. The comparative evidence argues strongly in favor of focusing more state capacity as an important factor in policy choice and outcomes and helps clarify the structures and processes that underlie capacity".

\section{References}

Bauman, Z. (2001). Globalization: Human consequences. México: Fondo de Cultura Económica.

Bresser-Pereira. (2007). State and market in the new developmentalism. Review New Society, July-August (210), 110-125.

Cox, R. H. (2001). The social construction of an imperative: Why welfare reform in Denmark and the Netherlands but not in Germany. World Politics, 53, 463-498.

Crouch, C. (2004). Post-democracy. Cambridge, UK.

Delfini, M., Drolas, A., \& Montes Cató, J. (2014). Recomposition labor and labor flexibility process in Argentina. México: Review Latin American Studies, 33, 105-126.

Document. (2011). Social and economic agreement for growth, employment and pension security. Retrieved from http://www.boe. es/buscar/doc.php?id=BOE-A-2011-2701

Document. (2012). International Labour Organization (ILO)_Report on the world of work 2012. Retrieved from http://www.ilo. org/wcmsp5/groups/public/@dgreports/@dcomm/@publ/documents/publication/wcms_179453.pdf

Document. (2013). International Labour Organization (ILO)—Report on world of work 2013: Regional brief on Latin America. Retrieved from http://www.ilo.org/global/research/global-reports/world-of-work/2013/WCMS_214387/lang--en /index.htm

Evans, P. (1996). The state as problem and solution: Predation, embedded, autonomy, and structural change. Review Economic Development, 35(140), 529-562.

Fumagalli, A., Lucarelli, S., Marazzi, C., Negri, A., \& Vercellone, C. (2009). Crisis in the global economy. Financial markets, social struggles, and new political scenarios. Verona, Italy: Uninomade.

Guy Peters, B. (2003). Institutional theory in political science: The new institutionalism. Barcelona: Gedisa.

Hall, P. (1993). Governing the economy. Madrid: Ministry of Labor, Employment and Social Security of Spain.

Instituto Nacional de Estadísticas y Censos (INDEC)—Ministry of Economy and Public Finance. (2013). Encuesta permanente de hogares. Mercado de trabajo, principales indicadores. Retrieved from http://www.indec.mecon.ar/uploads/ informesdeprensa/EPH_cont_1trim13.pdf

Laclau, E. (2012). Institutionalism and populism. Retrieved from http://tiempo.infonews.com/2012/08/29/editorial-84541institucionalismo--y-populismo.php

Laswell, H. (1970). The emerging conception of the policy sciences. Policy Sciences, 1(1), 3-14.

Laswell, H., \& Kaplan, A. (1950). Power and society. New Haven: Yale University Press.

Lindblom, C. (1991). The policy-making process. Madrid: Ministry for Public Administration.

Lindblom, C. (2000). The market system. United States of America: Yale University Press.

${ }^{10}$ Quoted in the book of Zygmunt Bauman: Globalization: Human Consequences. 


\section{RELATIONSHIP AMONG STATE, MARKET, AND POLITICAL ACTORS IN PUBLIC POLICIES}

Lora, E. (2012). Structural reforms in Latin American: What has been reformed and how to measure. Retrieved from $\mathrm{http} / /$ www.iadb.org/es/investigacion-y-datos/detalles-de-publicacion,3169.html?pub_id=IDB-WP-346

Margheritis, A. (1998). Implementing structural adjustment in Argentina: The politics of privatization. Review Problems of Latin America, 29, 99-123.

Marshall, T., \& Bottomore, T. (1998). Citizenship and social class. Madrid: Alianza.

Ministry of Labor, Employment and Social Security. (2013). Retrieved from http://www.trabajo.gob.ar/destacados/130116_i nformesociolaboral.asp

Molina, O., \& Rhodes, M. (2008). The political economy of adjustment in mixed market economies: A study of Spain and Italy. Proceedings from the VIII Spanish Congress of Political Science and Public Policy Administration for a Changing World. Spain.

Moreno, L. (2000). Precarious citizens: The safety net of social protection. Barcelona: Ariel, S.A.

North, D. (1993). Institutions and economic performance. México: Fondo de Cultura Económica.

O'Donnell, G. (1993). On the state, democratization and some conceptual problems. A Latin American view with glances at some post-communist countries. Review Economic Development, 33(130), 163-184.

Sartori, G. (2007). What is democracy? Madrid: Taurus.

Sckopol, T. (1989). Bringing the state back in: Strategies of analysis current research. Retrieved from http://respaldo.fcs.edu. uy/enz/ desarrollo/Skocpol.pdf

Subirats, J. (1992). A problem of style: The making of Spanish public policy: An investigation into the characteristic features of our policy style. Madrid, España: Constitutional Studies Center.

Tsebelis, G. (1990). Nested games: Rational choice in comparative politics. Berkeley: University of California Press.

Viñals, C., Chacartegui Jávega, C., Ramos Martín, F., \& Valle Muñoz. (2004). Labor policies: A multidisciplinary approach. Barcelona: UOC.

World of Work. (2013). Regional brief on Latin America. International Labour Organization. Retrieved from http://www.ilo.org/ global/research/global-reports/world-of-work/2013/WCMS_214387/lang--en/index.htm 